\title{
Systematic Mapping of Research on Farm-Level Sustainability in Finfish Aquaculture
}

\author{
Stefan Gunnarsson ${ }^{1, * \mathbb{C}}$, Katarina Arvidsson Segerkvist ${ }^{1} \mathbb{1}$, Torun Wallgren ${ }^{2}$, Per Hjelmstedt ${ }^{1}$, \\ Ulf Sonesson ${ }^{3}$ and Helena Hansson ${ }^{4}$ (D) \\ 1 Department of Animal Environment and Health, Swedish University of Agricultural Sciences (SLU), \\ P.O.B. 234, S-53223 Skara, Sweden; katarina.segerkvist@slu.se (K.A.S.); per.hjelmstedt@slu.se (P.H.) \\ 2 Department of Animal Environment and Health, Swedish University of Agricultural Sciences (SLU), \\ P.O.B. 7068, S-75007 Uppsala, Sweden; torun.wallgren@slu.se \\ 3 RISE Research Institutes of Sweden, P.O.B. 5401, S-40229 Göteborg, Sweden; ulf.sonesson@ri.se \\ 4 Department of Economics, Swedish University of Agricultural Sciences (SLU), P.O.B. 7013, \\ S-75007 Uppsala, Sweden; helena.hansson@slu.se \\ * Correspondence: stefan.gunnarsson@slu.se; Tel.: +46-511-67216
}

Received: 28 September 2020; Accepted: 27 November 2020; Published: 29 November 2020

\begin{abstract}
The sustainability of future finfish aquaculture needs to be improved to meet global environmental challenges. Global fish aquaculture production has expanded significantly recently, due to the increased demand for fish for human consumption. Therefore, it is important to mitigate challenges to the sustainability of the sector, such as pollution and depletion of natural resources. In this study, we systematically mapped the scientific literature on farm-level sustainability in fish aquaculture. The concept of sustainability was considered holistically, covering its economic, environmental and social dimensions, each consisting of a range of different aspects that may contradict or reinforce each other. Literature published between January 2000 and August 2020 with the geographical focus on Europe, Northern America and Australia-New Zealand was included. The search resulted in a total of 287 hits, but after the exclusion of articles that did not match the scope, only 17 papers remained for the systematic mapping. Of these, five papers covered all three dimensions of sustainability. Economic sustainability was addressed in 10 papers, environmental sustainability in 13 papers and social sustainability in 12 papers. This systematic mapping provides an important foundation for discussions and prioritisations of future actions to increase knowledge on farm-level sustainability in finfish aquaculture.
\end{abstract}

Keywords: environment; social; economic; animal welfare; ecology

\section{Introduction}

Aquaculture, i.e., farming of aquatic animals and plants, is the main source of aquatic food for human consumption and the fastest growing food sector globally [1]. The whole aquaculture sector includes more than 300 species of aquatic plants and animals, from single-cell algae to salmonids, and production systems range from indoor recirculating aquaculture systems (RASs) to outdoor floating net cage systems [2]. Aquaculture, hence, covers an extremely wide range of production forms and species compared with, e.g., pig or crop production. Globally, the majority of aquatic food production is situated in Asia, which has over $70 \%$ of global finfish production, with China contributing around half of the Asian total. Of the remaining global finfish production, $14 \%$ comes from the Americas, $10 \%$ from Europe, $7 \%$ from Africa and 1\% from Oceania [3]. The growing global human population, which is predicted to exceed 10 billion by 2055 [4], combined with a global increase in average per capita income and subsequently increasing demand for high-quality protein, has resulted 
in rapid growth in fish aquaculture. Consequently, the annual amount of farmed fish is steadily increasing, by $\sim 6 \%$ per annum since 1994 [1]. Since 2010, finfish production from aquaculture has actually exceeded production from captured fish [1,2], and the trend is expected to increase [2]. At the same time, there is growing public interest in the sustainability of fish production and increasing calls for better sustainability in fish farming practices [5,6].

Finfish aquaculture provides humans with a source of animal protein and also constitutes the main income for many farms and farming families around the world [3]. Fish aquaculture thereby contributes to some of the 17 global Sustainable Development Goals (SDGs) set by the United Nations in 2016, including SDG1: Zero hunger, SDG3: Good health and wellbeing and SDG8: Decent work and economic growth [7]. However, fish aquaculture may also jeopardise other SDGs, including SDG13: Climate action, SDG14: Life below water and SDG6: Clean water and sanitation. Major challenges of modern fish aquaculture include its contribution to emissions of greenhouse gases, loss of biodiversity and depletion of finite natural resources [8]. To achieve a sustainable future for aquaculture, it is critical that these challenges are overcome.

Sustainable food production (in agriculture and aquaculture) has previously been defined as the management and utilisation of the ecosystem in a way that maintains biological diversity, regeneration capacity, vitality, productivity and ability to fulfil significant ecological, economic and social functions at local, national and global level, today and in the future, and does not harm ecosystems [9]. Ecological aspects are central when considering sustainability in animal food production. However, the economic dimension of sustainability is also crucial, since revenues need to exceed production costs, at least over the long term, to sustain production. There are also specific aspects related to animal production, such as animal welfare, public health impacts and ethical considerations [10], which strongly influence social acceptance of production. Truly sustainable fish production requires these aspects to be taken into account. In fact, animal welfare has even been proposed as a fourth dimension of sustainable agriculture [10], and some studies have previously tried to incorporate animal welfare into life cycle analyses (LCAs) of animal production [11]. Furthermore, the different dimensions of sustainable development (environmental, economic, social) may be in conflict, meaning that there are trade-offs between them, or they may function to reinforce each other.

In aquaculture, environmental sustainability includes aspects ranging from the environmental impact of required feed production to the pollution caused by different production systems and management of the resulting harmful waste products. Nutrient pollution and emissions of, e.g., greenhouse gases are considerable environmental challenges that require identification of new solutions to reduce the environmental impact [12-14]. The escape of domestically cultivated fish species may interfere with wild populations of the same species, leading to interbreeding of wild and escaped farm fish, which can reduce the fitness of wild species, increase competition for resources and decrease wild fish populations [8]. Furthermore, the spread of diseases, e.g., parasites, by farmed fish populations is a threat to wild populations [6]. Production practices that lead to land exploitation and large-scale monocultures of grain and soy crops are another major environmental concern associated with the expansion of fish aquaculture [6]. However, in recent years there has been a trend for increasing net production in fish aquaculture in relation to resources used, although some carnivorous fish species, such salmon and trout, are still not contributing to this trend [15]. In the past, fish meal and fish oil were widely used for feeding livestock, particularly after the ban on the use of meat-and-bone meal $(\mathrm{MBM})$ in the European Union (EU) and other countries, due to the risk of transmission of bovine spongiform encephalomyelitis (BSE) [16]. However, livestock farmers have greater possibilities to replace the use of fishmeal due to price and preference changes than fish farmers [17].

The main sustainability and ethical concerns in aquaculture practices include environmental issues such as declines in wild fish populations due to use of wild-caught fish for feed, the introduction of non-indigenous species, the spread of diseases and habitat destruction [8]. Aquaculture also poses threats to the environment through chemical and waste discharge and destruction of ecosystems [6]. Moreover, animal welfare issues have been identified in fish aquaculture, such as physical pain in 
farmed fish, disease due to breeding, behavioural issues resulting from poorly adjusted densities (overcrowding) and stress caused by, e.g., fear, exhaustion or food deprivation [6]. The fish aquaculture industry has so far had difficulties resolving the issue of declining wild fish populations and in fact is continuing to exacerbate the decline, although some efforts of mitigation have been made. It can be concluded, however, that despite dissimilar views on animal and environmental ethics and differences in the results of empirical studies, the general consensus is that current aquaculture practices are not meeting the needs of fish or of the environment [6].

Efforts to develop more sustainable future fish aquaculture would benefit from a clear understanding of the current state, including how sustainability is considered and assessed in research. Future actions and research prioritisation could then be based on this understanding. The literature to date has considered various aspects of farm-level sustainability in fish aquaculture, but there have been no attempts to systematically map current knowledge.

The aim of this study was, therefore, to perform a systematic mapping of the scientific literature on sustainability performance in finfish aquaculture, including environmental, economic and social dimensions of sustainability. By systematically mapping existing literature on farm-level sustainability of finfish aquaculture in Europe, Northern America, Australia and New Zealand, important knowledge on sustainability in finfish aquaculture was collated. This knowledge is useful, as it provides a solid basis for highlighting research gaps and for prioritising future research to enhance sustainability.

\section{Materials and Methods}

\subsection{Definition of Fundamental Concepts}

The work presented in this paper is part of a larger project, other findings from which have been published previously [18-20].

\subsubsection{Environmental Sustainability}

The environmental sustainability dimension covers the ecosystem impacts of human activities, including emissions to the ecosystem and use of natural resources. Environmental sustainability can be investigated through several means, but the most commonly described is life cycle analysis (LCA). LCA considers the total resource in- and outflow of the production system including the input of, e.g., energy, minerals, feed and water and emissions of, e.g., waste and carbon dioxide. Analysis of the impacts caused by the emissions includes impacts from a local to global scale. In principle, all flows concerning the production system are mapped in an LCA, regardless of, e.g., economic ownership or organisational boundaries [21]. Environmental sustainability can also be assessed for more specific aspects, such as quantifying local impacts from, e.g., nutrient losses or toxic compounds from farms. In the present systematic mapping, we included LCA studies and studies on local impacts of fish aquaculture and associated feed production, such as emissions from farms through feed wastes and manure, changes in water quality and loss of biodiversity in the surrounding environment.

\subsubsection{Economic Sustainability}

The economic dimension of sustainability has two main perspectives: sustainable use of natural resources within an economic system or growth of an economic system. According to the first perspective, economic sustainability happens when economic activity is organised in such a way that natural resources are not harmed. The second perspective focuses on economic return on investment and does not necessarily take the natural resource capital into special consideration. Previous papers have distinguished between weak and strong sustainability, where natural resource and economic capital are considered jointly in weak sustainability, while the two types of capital are considered separately in strong sustainability [22,23]. By distinguishing between natural resource capital and economic capital, overexploitation of natural resources cannot be compensated for by high economic income, which can be the case if only the sum of economic and natural resources is evaluated. However, 
there is no consensus on how best to evaluate or measure economic sustainability [24]. Aspects such as cost, revenues, profit and investments have been proposed in frameworks for sustainability accounting [25] and can function as indicators to evaluate economic sustainability.

\subsubsection{Social Sustainability}

The social sustainability aspect is the least unified dimension of sustainability and has a broad scope [26]. Social sustainability has been defined as the ability of a community to develop a process and structures that meet the needs of current members, as well as supporting the ability of future generations to maintain a healthy community. Perhaps because of the loose definition, social sustainability is often the most overlooked dimension of sustainability. In this study, social sustainability was taken to include social equality, health equity, community development, labour rights, community resilience and animal welfare.

\subsection{Systematic Mapping Approach}

The current state of sustainability research within finfish aquaculture was investigated using a systematic approach in order to identify knowledge gaps within the research area. Systematic mapping has been described as a transparent, robust and repeatable method for identifying relevant literature and providing a structured overview of a specific topic or area $[27,28]$. The aim is to identify published papers within the specific area during a specific period, in order to find knowledge gaps, and provide useful information regarding, e.g., policy making or future research areas [29]. However, the method does not include any further synthesis of the study results and, thus, it differs from a systematic review, which aims to answer a specific question [29]. Therefore, in the present case, the systematic mapping was complemented with an evaluation of the studies identified, in order to assess how sustainability was incorporated in the studies, the dimensions of sustainability taken into consideration and how this was done. This further evaluation of the literature was done by analysing extracted keywords, which were defined and categorised to arrive at an overview of the aspects studied in the set of papers identified.

\subsection{Search of Literature}

A search for relevant scientific papers was conducted through specific search strings in three main literature databases: Scopus, Web of Science Core Collection and CABI: Cab Abstracts. The aim was to retrieve an unbiased sample of the published literature relevant to our research area. In order to identify papers relevant to the study area, the search string "("fish farm" ${ }^{*}$ OR agropiscicultur* OR aquaculture* OR piscicultur* OR aquaponic* OR (seafood W/2 farm*))" was added to the comprehensive search strings provided in Table 1 . The time span was set to include only papers published between 1 January 2000 and 27 August 2020. The identified papers were imported to EndNote $X 8^{\mathrm{TM}}$ as a separate library for papers identified from each database. When the search was completed and the libraries were combined, all duplicates were removed through the automatic function in the programme. Thereafter, paper titles and abstracts were manually analysed and any papers not relevant to the topic were removed. Relevant papers were defined as those addressing sustainability, conducted in one of the selected geographical areas (Europe, Northern America, Australia or New Zealand), available in English in full text and describing original research (i.e., not reviews). Book chapters and conference papers were excluded. Papers on finfish aquaculture specifically, and also on farm animal production explicitly including finfish aquaculture, were included. 
Table 1. Library search terms for environmental, economic and social sustainability.

\begin{tabular}{|c|c|}
\hline Sustainability Dimension & Search Terms ${ }^{1}$ \\
\hline Environmental & $\begin{array}{l}\text { ("environmental impact assessment" OR (environment* W/2 assessment) OR } \\
\text { (environment* W/2 impact) OR (environment* W/2 protection) OR (climate W/1 } \\
\text { change*) OR biodiversity OR ecosystem* OR pollution OR deforestation OR } \\
\text { eutrophication OR (habitat W/2 destruction) OR (land W/2 degradation) OR } \\
\text { (ozone W/2 depletion) OR "acid deposition" OR (odour W/2 emission) OR "air } \\
\text { quality" OR "biochemical oxygen demand*" OR "chemical oxygen demand*" } \\
\text { OR (nitrogen W/2 balance) OR (nitrogen W/2 cycle) OR (carbon W/2 cycle) OR } \\
\text { eco-toxicity OR "carbon footprint" OR LCA OR "life cycle assessment") }\end{array}$ \\
\hline Economic & $\begin{array}{l}\text { ((aquacultur* W/2 development) OR (aquacultur* W/2 production) OR (farm* } \\
\text { W/2 comparison*) OR (farm W/2 entrant*) OR (farm W/2 result*) OR (farm W/2 } \\
\text { development) OR production OR diversification OR intensification OR } \\
\text { "technical efficiency" OR "economic efficiency" OR "eco-efficiency" OR profit } \\
\text { OR econom* OR return OR "economic viability" OR "economic performance") }\end{array}$ \\
\hline Social & $\begin{array}{l}\text { ((attitude* W/2 work) OR labour OR labor OR (quality W/2 life) OR "living } \\
\text { condition*" OR "rural welfare" OR (work* W/2 condition*) OR "rural } \\
\text { development" OR "social welfare" OR "social security" OR "social service*" } \\
\text { OR "social equity" OR (health W/2 service*) OR "social status" OR (women W/2 } \\
\text { status) OR "equal right*" OR equality OR (rural W/2 employment) OR livability } \\
\text { OR "health equity" OR "labour rights" OR "labor rights" OR "social justice" } \\
\text { OR "social capital" OR (community W/2 development) OR (community } \\
\text { W/2 resilience)) }\end{array}$ \\
\hline
\end{tabular}

${ }^{1}$ For the searches in Web of Science Core Collection and CABI: CAB Abstracts, the Boolean operator NEAR was used, while for the search in Scopus, the Boolean operator W was used. *: is a symbol for truncation of word in library search.

\section{Results}

The search of the literature resulted in a total of 663 hits, of which 378 (57\%) were from CABI: Cab Abstracts, 165 (25\%) originated from Scopus and 120 (18\%) were found in Web of Science Core Collection. After removing duplicates, 287 unique papers were screened. However, after removal of articles that did not match the study scope (i.e., non-peer-reviewed reports, book chapters and reviews, or not from relevant geographic areas), only 17 papers remained (10 from Europe, five from North America and two from Australia/New Zealand). These 17 papers were used in the systematic mapping of the finfish aquaculture research area.

The 17 papers were first assessed for their coverage of the different dimensions of sustainability and whether one, two or all three dimensions were included (Table 2). During the mapping process, we found that aspects of environmental, economic or social sustainability were sometimes merely referred to in passing, e.g., mentioned in abstracts or introductions without being explored further in the text. The assessment showed that only five out of the 17 papers covered all three sustainability dimensions, while eight papers covered two dimensions and four covered only one dimension of sustainability (Figure 1).

Eleven papers focused on specific species (one or two species). The species covered were European seabass (Dicentrarchus labrax) (1), gilt-headed bream (Sparus aurata) (1), Atlantic salmon (Salmo salar) (4), rainbow trout (Oncorhynchus mykiss) (2), Nile tilapia (Oreochromis niloticus) (1), mojarra (Gerreidae sp.) (1), yellowtail kingfish (Seriola lalandi) (1), mulloway (Argyrosomus japonicus) (1) and European catfish (Silurus glanis) (1). One paper reviewed all the fish farmed within the selected study area (common carp (Cyprinus carpio), crucian carp (Carassius carassius), cornel (Ctenopharyngodon idella), novac/bighead carp (Hypophthalmichthys nobilis), fish cowboy (unspecified species), zander (Zander lucioperca), catfish (Siluris glanis) and unspecified species), although it only drew conclusions regarding the sustainability of organically reared carp [30]. Of the 17 papers identified, 10 focused on ocean-based farming, eight focused on land-based farming and the remaining papers did not state whether they studied land- or ocean-based farming. One paper investigated the economic potential for integrated 
systems. Three papers investigated new techniques and the development of new systems in order to meet the demands for environmental effects. Two papers focused entirely on levels of potentially harmful substances in farmed fish, one of which investigated whether it is possible to reduce the levels of harmful substances through feed.

Table 2. Inclusion of different sustainability aspects in the set of 17 relevant papers identified.

\begin{tabular}{|c|c|c|c|c|}
\hline \multirow{2}{*}{ Paper } & \multirow[b]{2}{*}{ Aim } & \multicolumn{3}{|c|}{ Key Words } \\
\hline & & Social Sustainability & $\begin{array}{c}\text { Economic } \\
\text { Sustainability }\end{array}$ & $\begin{array}{l}\text { Environmental } \\
\text { Sustainability }\end{array}$ \\
\hline Brattland, 2013 [32] & $\begin{array}{c}\text { Investigation of effects of fishers' } \\
\text { ecological knowledge and its } \\
\text { influence on policy making }\end{array}$ & $\begin{array}{l}\text { Conflicts/decision } \\
\text { making fishermen/ } \\
\text { aquaculture }\end{array}$ & & Ecological knowledge \\
\hline $\begin{array}{l}\text { Bunting \& Shpigel, } \\
2009[33]\end{array}$ & $\begin{array}{l}\text { Bio-economic modelling of } \\
\text { integrated systems }\end{array}$ & & $\begin{array}{l}\text { Internal rate of } \\
\text { return }\end{array}$ & \\
\hline $\begin{array}{l}\text { Calone et al., } \\
2019 \text { [34] }\end{array}$ & $\begin{array}{l}\text { Improving water management in } \\
\text { aquaponics systems }\end{array}$ & & & Water usage \\
\hline Cowx, 2015 [36] & $\begin{array}{l}\text { Exploration of changes to assist } \\
\text { planning and management }\end{array}$ & $\begin{array}{l}\text { Employment, revenue, } \\
\text { social benefits }\end{array}$ & & \\
\hline $\begin{array}{l}\text { Fenemor et al., } \\
\quad 2008 \text { [37] }\end{array}$ & $\begin{array}{l}\text { Modelling tools for integrated } \\
\text { catchment management }\end{array}$ & Job numbers & Gross output & $\begin{array}{l}\text { Water flow, nitrogen load, } \\
\text { sediment yield, carbon } \\
\text { sink rate, nitrogen yield }\end{array}$ \\
\hline $\begin{array}{c}\text { Floysand \& } \\
\text { Jakobsen, } 2017[38]\end{array}$ & $\begin{array}{l}\text { Investigation of change through } \\
\text { technology }\end{array}$ & $\begin{array}{l}\text { Rural development } \\
\text { narrative }\end{array}$ & $\begin{array}{l}\text { The global demand } \\
\text { narrative }\end{array}$ & $\begin{array}{c}\text { Environmental } \\
\text { degradation narrative }\end{array}$ \\
\hline $\begin{array}{l}\text { Hamouda et al., } \\
2005 \text { [39] }\end{array}$ & $\begin{array}{l}\text { Examination of strategic conflicts } \\
\text { over aquaculture development }\end{array}$ & $\begin{array}{l}\text { Threats to human } \\
\text { rights, resource } \\
\text { conflicts }\end{array}$ & $\begin{array}{l}\text { Aquaculture } \\
\text { expansion }\end{array}$ & $\begin{array}{l}\text { Resource conflict, } \\
\text { environmental impact }\end{array}$ \\
\hline $\begin{array}{l}\text { Otchere et al., } \\
2004 \text { [43] }\end{array}$ & $\begin{array}{l}\text { Investigation of the possibility to } \\
\text { use open pits for aquaculture }\end{array}$ & New income & $\begin{array}{c}\text { Economic } \\
\text { diversification, } \\
\text { income/employment }\end{array}$ & $\begin{array}{l}\text { Low risk of escapes, } \\
\text { unclean water }\end{array}$ \\
\hline $\begin{array}{l}\text { Padula et al., } \\
2012 \text { [44] }\end{array}$ & $\begin{array}{l}\text { Levels of residues in yellowtail } \\
\text { kingfish }\end{array}$ & $\begin{array}{l}\text { Food safety, } \\
\text { market access }\end{array}$ & & $\begin{array}{l}\text { Various environmental } \\
\text { toxins }\end{array}$ \\
\hline $\begin{array}{l}\text { Rigby et al., } \\
2017 \text { [45] }\end{array}$ & $\begin{array}{l}\text { Examination of cycles of growth } \\
\text { and crisis within Newfoundland } \\
\text { aquaculture }\end{array}$ & $\begin{array}{l}\text { Corporate social } \\
\text { responsibility }\end{array}$ & & $\begin{array}{l}\text { Genetic pollution, } \\
\text { infectious disease }\end{array}$ \\
\hline $\begin{array}{l}\text { Spanu \& Florea, } \\
2018[30]\end{array}$ & $\begin{array}{l}\text { Review of existing situation in } \\
\text { Giurgiu county, Romania }\end{array}$ & $\begin{array}{l}\text { Guaranteed payment, } \\
\text { optimal hygiene and } \\
\text { control procedures, } \\
\text { non-discriminatory } \\
\text { treatment to all trading } \\
\text { partners, traceability }\end{array}$ & & $\begin{array}{l}\text { Biodiversity, ecological } \\
\text { aquaculture, balanced } \\
\text { exploitation }\end{array}$ \\
\hline $\begin{array}{l}\text { Suryanata \& } \\
\text { Umemoto, } \\
2005 \text { [46] }\end{array}$ & Environmental planning & $\begin{array}{c}\text { Social and cultural } \\
\text { issues (e.g., integrity, } \\
\text { communication, values } \\
\text { and vision) }\end{array}$ & $\begin{array}{l}\text { Economic issues } \\
\text { (e.g., market } \\
\text { competition and } \\
\text { impact on fish } \\
\text { price, local and } \\
\text { export market) }\end{array}$ & $\begin{array}{l}\text { Environmental impacts } \\
\text { (e.g., impact on coral reefs, } \\
\text { bacteria and disease) }\end{array}$ \\
\hline
\end{tabular}




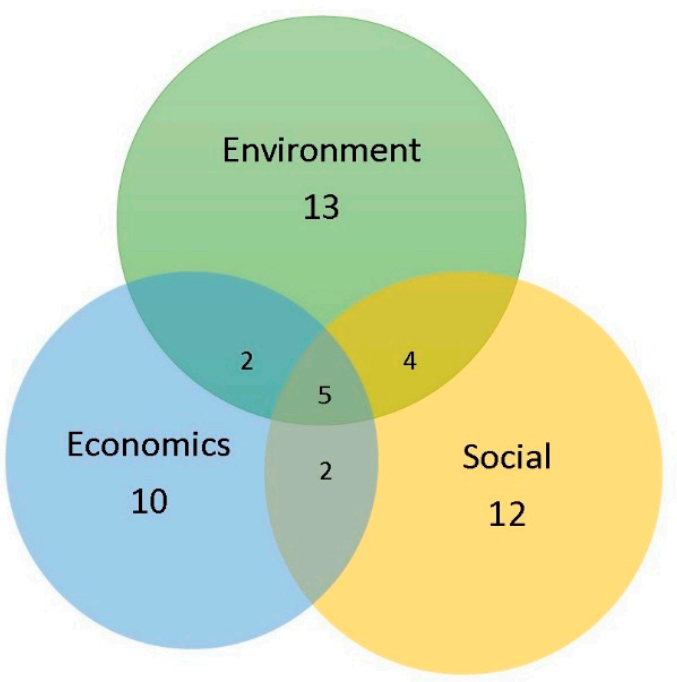

Figure 1. Number of the finfish aquaculture articles identified $(n=17)$ covering and/or mentioning the three different dimensions of sustainability. One paper covered only economic sustainability, one paper covered only social sustainability and two papers covered only environmental sustainability.

Environmental sustainability was the most commonly applied sustainability dimension, covered in 13 of the papers (Figure 1). Economic sustainability was covered in 10 papers and social sustainability in 12 papers in total (Figure 1).

\section{Discussion}

We applied a systematic mapping method to obtain an overview of the current scientific literature (defined as original research papers published in peer-reviewed journals) on farm-level sustainability in finfish aquaculture, including the social, environmental and economic dimensions of sustainability. The method enabled identification of the state of this research area, providing a basis for discussing knowledge gaps. In the systematic mapping, our aim was to create search terms wide enough to identify as many relevant papers as possible. However, it should be acknowledged that the search string may have omitted relevant results through not including certain specific wordings, which may have led to biased results. As an example, terms such as "growth" and "feed efficiency" were not used, and there might have been more studies published on ways of reducing the environmental impact and technical reports that were excluded. In order to minimise the risk of not identifying relevant papers, we created broad and comprehensive search terms. Irrelevant papers were manually removed and were, therefore, not a major risk factor for the conclusions drawn from this study.

We found that only a limited number of the papers identified (17/287) aimed to investigate sustainability at all. Of the 17 papers retained in the final set, only five covered all three dimensions of sustainability, while four papers covered only one sustainability dimension without mentioning the other dimensions. The majority of the papers (13) investigated environmental sustainability in some form, followed by social sustainability (12) and economic sustainability (10). There was some overlap between studies regarding the different dimensions of sustainability, with two papers investigating both environmental and economic sustainability, two papers investigating economic and social sustainability, and four papers investigating environmental and social sustainability. Papers combining environmental and social sustainability were more common than papers considering environmental and economic sustainability. Economic sustainability was also more commonly covered or mentioned in association with one of the other two dimensions than on its own. Not all papers identified had sustainability as their main object, but rather included conclusions, reflections or discussions covering sustainability, so they were considered eligible for our synthesis. However, our systematic mapping revealed that the current literature (although multiple dimensions were mentioned in several papers) does not describe 
these interrelations or discuss possible trade-offs or synergies between different aspects. This reveals an important area for future research and emphasises the need for more comprehensive studies regarding all dimensions of sustainability within fish aquaculture. The small number of publications is surprising, considering that sustainability has been discussed in society for more than three decades, since the publication of the Brundtland report in 1987 [47], and the fact that fish aquaculture is an important part of the animal food production system in many countries.

The papers identified reflected on the fact that aquaculture as an industry has increased rapidly in order to meet the increased demand for fish as the supply of wild-caught fish has decreased. They also pointed out a great risk of aquaculture having a negative impact on the environment regarding eutrophication, disease control and spread of invasive species or exploitation of the surrounding ecosystems. Many of the papers also indicated that that regulatory bodies, policy makers and scientists cannot keep up with the fast pace of development and its impact on, e.g., the social or environmental sustainability of fish aquaculture. One paper noted that aquaculture has sometimes been viewed as a self-generating economic activity and that use of fossil fuels, medicals and chemicals has enabled maximum economic output, while not taking environmental or social sustainability into consideration [48]. In general, the content in the 17 papers identified was scattered and mainly consisted of case studies and modelling/analysis of production methods. The environmental impact (and indirect economic and social impacts) from, e.g., farmed fish escapes and the spread of disease was not covered in any of the papers.

Compared with previous systematic mappings of other farmed animals [18-20,49] which have commonly focused on a specific species, the topic of fish aquaculture covers multiple species. Globally, freshwater fish species currently dominate aquaculture fish production, with freshwater carp and cyprinids constituting over $53.1 \%$ of total fish production, followed by miscellaneous freshwater fish species (19.5\%), tilapia and other cichlids (11.0\%), diadromous salmonids $(6.5 \%)$ and miscellaneous coastal fish species. By value, the top fish species in the world is reported to be Atlantic salmon, followed by the cyprinids grass carp and silver carp (Hypophthalmichthys molitrix) [2]. The 17 papers identified in this study covered at least 13 species, including the commonly occurring Atlantic salmon, which was represented in three papers. Global aquaculture consists of far more species, however. The different species have different needs and may affect the surrounding environment differently, depending on, e.g., their habitat or feeding regime. It is, therefore, likely that sustainability-related questions may differ from one species to the next. The results of the present study show that there are large knowledge gaps when it comes to different systems and different species.

The social sustainability of fish aquaculture is complex [26]. Social sustainability was covered in 12 of the 17 papers identified, with these papers focusing more or less on conflicts between the fish industry and populations potentially affected by new aquaculture, and on how societies are affected by existing aquaculture. Extrapolation of the results and discussions revealed that all stakeholder groups affected by aquaculture must be involved in policy making in order to avoid unnecessary conflicts and formulate fair and sustainable regulations. Examples of affected groups mentioned in the papers were the industry, which values profit; fishermen of wild fish, who view competition and possible escapes from aquaculture as a problem, and the wider society, which wants to avoid deterioration of the environment and of nearby ecosystems. Some of the papers pointed out that the development of small-scale aquaculture can bring income to smaller communities with livelihood issues. Others pointed out that there is potential to use, e.g., old open pits as dams for fish farming, as compensation for loss of income after closed mines or as a way of managing water resources and reducing the impact of other potentially environmentally damaging activities, such as deforestation. A study in Newfoundland by Rigby et al. [45] claimed that the Canadian aquaculture industry is so potent that environmental and social considerations are disregarded, because regulation of these would risk affecting the economy too much.

Another social sustainability aspect of aquaculture discussed in the selected set of papers was the use of antimicrobials resulting in residues and antibiotic-resistant bacteria in water, which can easily be 
spread and transmitted to other locations, even when diluted in vast volumes of water. Furthermore, residuals in food products were identified as a direct threat to human health [50,51]. Another significant aspect mentioned was the importance of preserving animal biodiversity. One study pointed out that some aquaculture diminishes wild fisheries through, e.g., habitat modification, collecting and rearing wild fish instead of in-house breeding, introduction of exotic species or pathogens, use of wild fish as fish feed and nutrient pollution [52]. On the other hand, fish aquaculture contributes to food security and provides consumers with an affordable protein source [52]. Animal welfare has previously been suggested to represent a fourth dimension of sustainability or to form part of social sustainability. Interestingly, none of the papers identified mentioned animal welfare and sustainability, while this issue is more commonly mentioned in relation to sustainability among other farm animals [18-20,49]. Improving health through preventative management within aquaculture production can improve animal welfare, production efficiency and production economics, through reduced costs and increased productivity [51]. Improved production efficiency can also increase environmental sustainability, as it improves exploitation of resources through, e.g., improved feed efficiency and social sustainability (public health) [51,53]. However, improved animal welfare through, e.g., decreased stocking density will also result in potentially large economic costs, which has been raised as a concern by producers (e.g., [54]).

The environment was mentioned in most of the articles identified, but mainly in a sub-sentence primarily discussing social or economic sustainability. Thus, at first glance, the environmental aspect appeared to be more widely investigated than it actually was (Figure 1). Analyses or modelling of how inferior environments affect the population or adaptations to the environment that must be made when aquaculture is expanded or introduced in new areas are examples of dimensions of environmental sustainability that were taken into consideration in the relevant papers. The sustainability of these systems may be improved, according to these papers; e.g., Calone and co-workers [34] reported that integrated catfish and lettuce cultivation had a lower environmental impact than when cultivation was performed separately, as wastewater was recovered for crop cultivation and then recycled back to the fish tanks. The major conclusion from the 17 papers identified in our systematic mapping was that technical development is possible and necessary from both an environmental and economic perspective. The papers also revealed concerns regarding alien species, competition with existing fisheries and/or deteriorating water quality, but mostly in correlation with failing social sustainability. An example is that aquaponics systems (recirculating productive aquaculture systems) recycle fish waste products, in order to reduce the concentrations of waste in outflow water, thereby reducing the environmental impact through contamination. The existing regulations were said to be often unclear, and some papers expressed concerns regarding the industry having too great an influence, as it can also be an important economic sector in a region. Much knowledge is lacking, but some studies suggested modelling in order to identify suitable areas for the development of aquaculture, so that it can take place in an environmentally sustainable way or adapt to future changes in water temperatures caused by climate change.

The economic aspects raised in the papers identified can be categorised as relating to large- or small-scale production. Development of small-scale aquaculture was reported to have a possible positive impact on rural areas, through job opportunities and increased social sustainability. Large-scale aquaculture was reported to be somewhat unregulated in many areas, which has created conflict with other traders (e.g., fisheries and tourism). The overall conclusion from the papers is that changes are necessary, but may be associated with large costs (at least initially) and must take place in discussion with all affected stakeholder in the immediate area, to ensure that they do not affect the financial sustainability of other affected industries.

Through this systematic mapping of the literature, we provide a basis for discussion regarding the research gaps on sustainability within fish aquaculture. Based on our review of the relevant literature, we identified the following particular research gaps: a lack of studies regarding sustainability, including studies where the three dimensions of sustainability and their inter-correlations are investigated; 
studies on the full diversity of species used in fish aquaculture, which involves a wide number of species with different production prerequisites; and research on integration of animal welfare within the area of fish aquaculture.

We found that, to date, only a few studies have specifically investigated the sustainability of fish aquaculture (regardless of the sustainability dimension). Therefore, the development of a more holistic sustainability assessment framework that covers all three dimensions is needed in order to facilitate thorough empirical studies on the subject. Further, coverage of all three sustainability dimensions within sustainability studies is needed in order to increase understanding of the interactions between the dimensions, which is critical for the development of sustainable production on all levels. Hence, future research should apply an interdisciplinary approach in order to handle the complex matter of sustainability spanning several scientific fields.

The complexity of sustainability within aquaculture is increased by the large number of species involved and their heterogeneity. This calls for more species-specific research, as it may not be possible to extrapolate findings from one species in one context to other species or other contexts.

Animal welfare is an increasing concern within farm animal production and aquaculture. The importance of fish welfare has been underestimated historically, but it is still surprising that there is no mention of animal welfare with regard to sustainability in published studies on finfish aquaculture. Incorporation of animal welfare issues within finfish aquaculture sustainability may therefore be necessary in order to increase awareness of animal welfare in the finfish production industry.

\section{Conclusions}

In this study, the scientific literature regarding finfish aquaculture was systematically mapped concerning the three dimensions of sustainable development (environmental, economic and social sustainability). The mapping revealed that only a small fraction (2.6\%) of 17 relevant papers identified concerned sustainability. Of these papers, only five covered all three sustainability dimensions within aquaculture, while papers covering one or two of the dimensions were more common. Moreover, correlations such as trade-offs or synergies between the different sustainability dimensions were rarely investigated or discussed. These findings provide an important foundation for discussion and prioritisation of future actions to increase knowledge on farm-level sustainability in finfish aquaculture.

Author Contributions: Conceptualisation, S.G., H.H., U.S. and K.A.S.; Investigation, K.A.S., P.H. and T.W.; Data Curation, P.H. and T.W.; Formal Analysis, K.A.S., P.H. and T.W.; Writing-Original Draft Preparation, T.W. and S.G.; Review and Editing, H.H., U.S., K.A.S., P.H., T.W and S.G.; Funding Acquisition, S.G. All authors have read and agreed to the published version of the manuscript.

Funding: The Swedish Research Council Formas, grant number 2017-02017, funded this research.

Acknowledgments: We thank Mattias Lennartsson, librarian at the Swedish University of Agricultural Sciences, for valuable help during the process of developing the search strings.

Conflicts of Interest: The authors declare no conflict of interest. The funders had no role in the design of the study; in the collection, analyses, or interpretation of data; in the writing of the manuscript; or in the decision to publish the results.

\section{References}

1. FAO. FAOSTAT Database. Available online: http://www.fao.org/faostat/en/\#home (accessed on 28 September 2020).

2. Tacon, A.G.J. Trends in Global Aquaculture and Aquafeed Production: 2000-2017. Rev. Fish. Sci. Aquacult. 2020, 28, 43-56. [CrossRef]

3. FAO. The State of World Fisheries and Aquaculture 2020; Food and Agriculture Organization of the United Nations: Rome, Italy, 2020; p. 244.

4. UN. Probabilistic Population Projections Based on the World Population Prospects: The 2017 Revision. Available online: https://www.un.org/development/desa/publications/world-population-prospects-the-2017revision.html (accessed on 28 September 2020). 
5. Lambooij, E.; Kloosterboer, R.; Gerritzen, M.; Vis, J.D. Head-only electrical stunning and bleeding of African catfish (Clarias gariepinus): Assessment of loss of consciousness. Anim. Welf. 2004, 13, 71-76.

6. Bergqvist, J.; Gunnarsson, S. Finfish Aquaculture: Animal Welfare, the Environment, and Ethical Implications. J. Agric. Environ. Ethics 2013, 26, 75-99. [CrossRef]

7. UN. Sustainable Development Goals. Available online: https://www.un.org/development/desa/en/news/ sustainable/sustainable-development-goals.html (accessed on 28 September 2020).

8. Naylor, R.; Hindar, K.; Fleming, I.A.; Goldburg, R.; Williams, S.; Volpe, J.; Whoriskey, F.; Eagle, J.; Kelso, D.; Mangel, M. Fugitive Salmon: Assessing the Risks of Escaped Fish from Net-Pen Aquaculture. BioScience 2005, 55, 411, 427-437. [CrossRef]

9. Tilman, D.; Cassman, K.G.; Matson, P.A.; Naylor, R.; Polasky, S. Agricultural sustainability and intensive production practices. Nature 2002, 418, 671-677. [CrossRef] [PubMed]

10. Stern, S.; Sonesson, U.; Gunnarsson, S.; Öborn, I.; Kumm, K.I.; Nybrant, T. Sustainable development of food production: A case study on scenarios for pig production. AMBIO 2005, 34, 402-407. [CrossRef]

11. Scherer, L.; Tomasik, B.; Rueda, O.; Pfister, S. Framework for integrating animal welfare into life cycle sustainability assessment. Int. J. Life Cycle Assess. 2018, 23, 1476-1490. [CrossRef]

12. Chávez-Fuentes, J.J.; Capobianco, A.; Barbušová, J.; Hutňan, M. Manure from our agricultural animals: A quantitative and qualitative analysis focused on biogas production. Waste Biomass Valorization 2017, 8, 1749-1757. [CrossRef]

13. Xin, H.; Gates, R.S.; Green, A.R.; Mitloehner, F.M.; Moore, P.A.; Wathes, C.M. Environmental impacts and sustainability of egg production systems. Poultr. Sci. 2011, 90, 263-277. [CrossRef]

14. Sarikaya, E.; Demirer, G.N. Biogas production from broiler manure, wastewater treatment plant sludge, and greenhouse waste by anaerobic co-digestion. J. Renew. Sustain. Energy 2013, 5. [CrossRef]

15. Kok, B.; Malcorps, W.; Tlusty, M.F.; Eltholth, M.M.; Auchterlonie, N.A.; Little, D.C.; Harmsen, R.; Newton, R.W.; Davies, S.J. Fish as feed: Using economic allocation to quantify the Fish In: Fish Out ratio of major fed aquaculture species. Aquaculture 2020, 528, 735474. [CrossRef]

16. European Commission. Regulation (EC) No 999/2001 of the European Parliament and of the CounciL of 22 May 2001 Laying Down Rules for the Prevention, Control and Eradication of Certain Transmissible Spongiform Encephalopathies; European Commission: Brussels, Belgium, 2001; p. 40.

17. Naylor, R.L.; Hardy, R.W.; Bureau, D.P.; Chiu, A.; Elliott, M.; Farrell, A.P.; Forster, I.; Gatlin, D.M.; Goldburg, R.J.; Hua, K.; et al. Feeding aquaculture in an era of finite resources. Proc. Natl. Acad. Sci. USA 2009, 106, 15103-15110. [CrossRef] [PubMed]

18. Gunnarsson, S.; Arvidsson Segerkvist, K.; Göransson, L.; Hansson, H.; Sonesson, U. Systematic Mapping of Research on Farm-Level Sustainability in Egg and Chicken Meat Production. Sustainability 2020, 12, 3033. [CrossRef]

19. Gunnarsson, S.; Arvidsson Segerkvist, K.; Wallgren, T.; Hansson, H.; Sonesson, U. A Systematic Mapping of Research on Sustainability Dimensions at Farm-level in Pig Production. Sustainability 2020, 12, 4352. [CrossRef]

20. Arvidsson Segerkvist, K.; Hansson, H.; Sonesson, U.; Gunnarsson, S. Research on Environmental, Economic, and Social Sustainability in Dairy Farming: A Systematic Mapping of Current Literature. Sustainability 2020, 12, 5502. [CrossRef]

21. Notarnicola, B.; Sala, S.; Anton, A.; McLaren, S.J.; Saouter, E.; Sonesson, U. The role of life cycle assessment in supporting sustainable agri-food systems: A review of the challenges. J. Clean. Prod. 2017, 140, 399-409. [CrossRef]

22. Ayres, R.U.; van den Bergh, J.C.J.M.; Gowdy, J.M. Strong versus weak sustainability: Economics, natural sciences and 'consilience'. Environ. Ethics 2001, 23, 155-168. [CrossRef]

23. van den Bergh, J.C.J.M. Externality or sustainability economics? Ecol. Econ. 2010, 69, 2047-2052. [CrossRef]

24. Montiel, I.; Delgado-Ceballos, J. Defining and Measuring Corporate Sustainability: Are We There Yet? Organ. Environ. 2014, 27, 113-139. [CrossRef]

25. Alliances, G.S. Global Reporting Initiative. Available online: https:/www.globalreporting.org/standards/ (accessed on 28 September 2020).

26. Vallance, S.; Perkins, H.C.; Dixon, J.E. What is social sustainability? A clarification of concepts. Geoforum 2011, 42, 342-348. [CrossRef] 
27. Snilstveit, B.; Vojtkova, M.; Bhavsar, A.; Stevenson, J.; Gaarder, M. Evidence \& Gap Maps: A tool for promoting evidence informed policy and strategic research agendas. J. Clin. Epidemiol. 2016, 79, 120-129. [CrossRef] [PubMed]

28. Petersen, K.; Vakkalanka, S.; Kuzniarz, L. Guidelines for conducting systematic mapping studies in software engineering: An update. Inf. Softw. Technol. 2015, 64, 1-18. [CrossRef]

29. James, K.L.; Randall, N.P.; Haddaway, N.R. A methodology for systematic mapping in environmental sciences. Environ. Evid. 2016, 5, 7. [CrossRef]

30. Spânu, S.; Florea, M. Analysis of the aquaculture sector at the level of Giurgiu county. Sci. Pap. Ser. Manag. Econ. Eng. Agric. Rural Dev. 2018, 18, 325-332.

31. Baldan, D.; Porporato, E.M.D.; Pastres, R.; Brigolin, D. An R package for simulating growth and organic wastage in aquaculture farms in response to environmental conditions and husbandry practices. PLoS ONE 2018, 13, e0195732. [CrossRef]

32. Brattland, C. Proving Fishers Right. Effects of the Integration of Experience-Based Knowledge in Ecosystem-Based Management. Acta Boreal. 2013, 30, 39-59. [CrossRef]

33. Bunting, S.W.; Shpigel, M. Evaluating the economic potential of horizontally integrated land-based marine aquaculture. Aquaculture 2009, 294, 43-51. [CrossRef]

34. Calone, R.; Pennisi, G.; Morgenstern, R.; Sanye-Mengual, E.; Lorleberg, W.; Dapprich, P.; Winkler, P.; Orsini, F.; Gianquinto, G. Improving water management in European catfish recirculating aquaculture systems through catfish-lettuce aquaponics. Sci. Total Environ. 2019, 687, 759-767. [CrossRef]

35. Chen, X.; Samson, E.; Tocqueville, A.; Aubin, J. Environmental assessment of trout farming in France by life cycle assessment: Using bootstrapped principal component analysis to better define system classification. J. Clean. Prod. 2015, 87, 87-95. [CrossRef]

36. Cowx, I.G. Characterisation of inland fisheries in Europe. Fish. Manag. Ecol. 2015, 22, 78-87. [CrossRef]

37. Fenemor, A.; Deans, N.; Davie, T.; Allen, W.; Dymond, J.; Kilvington, M.; Phillips, C.; Basher, L.; Gillespie, P.; Young, R.; et al. Collaboration and modelling-Tools for integration in the Motueka catchment, New Zealand. Water SA 2008, 34, 448-455. [CrossRef]

38. Fløysand, A.; Jakobsen, S.-E. Industrial renewal: Narratives in play in the development of green technologies in the Norwegian salmon farming industry. Geogr. J. 2017, 183, 140-151. [CrossRef]

39. Hamouda, L.; Hipel, K.W.; Marc Kilgour, D.; Noakes, D.J.; Fang, L.; McDaniels, T. The salmon aquaculture conflict in British Columbia: A graph model analysis. Ocean. Coast. Manag. 2005, 48, 571-587. [CrossRef]

40. Hermansen, Ø.; Heen, K. Norwegian Salmonid Farming and Global Warming: Socioeconomic Impacts. Aquac. Econ. Manag. 2012, 16, 202-221. [CrossRef]

41. Iagaru, R.; Florescu, N.; Iagaru, P. Strategic management of sustainable development in the countryside of sibiu depression-Basic of environmental protection. Environ. Eng. Manag. J. 2016, 15, 11. [CrossRef]

42. Lefrançois, P.; Puigagut, J.; Chazarenc, F.; Comeau, Y. Minimizing phosphorus discharge from aquaculture earth ponds by a novel sediment retention system. Aquacult. Eng. 2010, 43, 94-100. [CrossRef]

43. Otchere, F.A.; Veiga, M.M.; Hinton, J.J.; Farias, R.A.; Hamaguchi, R. Transforming open mining pits into fish farms: Moving towards sustainability. Nat. Resour. Forum 2004, 28, 216-223. [CrossRef]

44. Padula, D.J.; Madigan, T.L.; Nowak, B.F. Australian farmed Yellowtail Kingfish (Seriola lalandi) and Mulloway (Argyrosomus hololepidotus): Residues of metallic, agricultural and veterinary chemicals, dioxins and polychlorinated biphenyls. Chemosphere 2012, 86, 709-717. [CrossRef]

45. Rigby, B.; Davis, R.; Bavington, D.; Baird, C. Industrial aquaculture and the politics of resignation. Mar. Policy 2017, 80, 19-27. [CrossRef]

46. Suryanata, K.; Umemoto, K. Beyond environmental impact: Articulating the "intangibles" in a resource conflict. Geoforum 2005, 36, 750-760. [CrossRef]

47. Brundtland, G.H. Our Common Future-Call for Action. Environ. Conserv. 1987, 14, 291-294. [CrossRef]

48. Folke, C.; Kautsky, N. Aquaculture with its environment: Prospects for sustainability. Ocean. Coast. Manag. 1992, 17, 5-24. [CrossRef]

49. Arvidsson Segerkvist, K.; Hansson, H.; Sonesson, U.; Gunnarsson, S. Research on Environmental, Economic, and Social Sustainability in Dairy Farming: A systematic mapping of current literature on sustainability in beef cattle and sheep farming. Sustainability 2020, unpublished.

50. Silbergeld, E.K.; Graham, J.; Price, L.B. Industrial Food Animal Production, Antimicrobial Resistance, and Human Health. Annu. Rev. Public Health 2008, 29, 151-169. [CrossRef] [PubMed] 
51. Amador, P.; Duarte, I.M.; da Costa, R.P.R.; Fernandes, R.; Prudencio, C. Characterization of Antibiotic Resistance in Enterobacteriaceae From Agricultural Manure and Soil in Portugal. Soil Sci. 2017, 182, $292-301$. [CrossRef]

52. Naylor, R.L.; Goldburg, R.J.; Primavera, J.H.; Kautsky, N.; Beveridge, M.C.M.; Clay, J.; Folke, C.; Lubchenco, J.; Mooney, H.; Troell, M. Effect of aquaculture on world fish supplies. Nature 2000, 405, 1017-1024. [CrossRef] [PubMed]

53. Mie, A.; Andersen, H.R.; Gunnarsson, S.; Kahl, J.; Kesse-Guyot, E.; Rembialkowska, E.; Quaglio, G.; Grandjean, P. Human health implications of organic food and organic agriculture: A comprehensive review. Environ. Health 2017, 16, 22. [CrossRef]

54. Tudorache, M.; Custura, I.; Van, I.; Miclosanu, E.P.; Vidu, L. Influence of applying broiler welfare laws on unit cost. Sci. Pap. Ser. D Anim. Sci. 2014, 57, 212-215.

Publisher's Note: MDPI stays neutral with regard to jurisdictional claims in published maps and institutional affiliations.

(C) 2020 by the authors. Licensee MDPI, Basel, Switzerland. This article is an open access article distributed under the terms and conditions of the Creative Commons Attribution (CC BY) license (http://creativecommons.org/licenses/by/4.0/). 